Os artigos dos Textos para Discussão da Escola de Economia de São Paulo da Fundação Getulio Vargas são de inteira responsabilidade dos autores e não refletem necessariamente a opinião da FGV-EESP. É permitida a reprodução total ou parcial dos artigos, desde que creditada a fonte.

Escola de Economia de São Paulo da Fundação Getulio Vargas FGV-EESP www.eesp.fgv.br 


\title{
Models of developmental state
}

\author{
Luiz Carlos Bresser-Pereira
}

July 2016.

\begin{abstract}
This paper searches to understand the developmental state and its historical role in the industrial revolution and after it. First, the developmental state is defined as an alternative to the liberal state. Second, it was in the framework of a developmental state that industrial revolutions took place, and four models of developmental state are defined. Third, after the industrial revolution, the state withdraws partially from the economy, but the developmental state continues to have a major role in assuring the general conditions that make competitive the competent business enterprises in each country - in conducing an active macroeconomic policy, particularly an exchange rate policy, in coordinating the non-competitive industries, and in conducing strategic industrial and technological policy. The paper concludes by comparing developmentalism with nationalism.
\end{abstract}

Key words: Developmental state, developmentalism, economic liberalism, nationalism

Resumo. Este artigo busca compreender o Estado desenvolvimentista e seu papel histórico na revolução industrial e depois dela. Em primeiro lugar, o Estado desenvolvimentista é definido como uma alternativa para o Estado liberal. Em segundo lugar vemos que foi no quadro de um Estado desenvolvimentista que as revoluções industriais ocorreram, e quatro modelos de Estado desenvolvimentista são definidos. Em terceiro lugar, depois da revolução industrial, o Estado se retira parcialmente da economia, mas o Estado de desenvolvimento continua a ter um papel importante em assegurar as condições gerais que tornam competitivas as empresas competentes de cada país - na condução de uma política macroeconômica ativa, particularmente um política cambial, na coordenação do sector nãocompetitivo da economia, e na condução de política industrial e tecnológica estratégica. 0 documento conclui, comparando desenvolvimentismo com o nacionalismo.

Palavras-chave: Estado desenvolvimentista, desenvolvimentismo, liberalismo econômico, nacionalismo

JEL Classification: 010, 011 and 019

In the 1950s, Brazilian political scientists and economists identified "developmentalism" as the set of political ideas and economic strategies that drove Brazil's accelerated industrialization and the coalition of social classes identified with national development. Hélio Jaguaribe (1962: 208) stated in the early 1960s that "the

Agradeço a Marcus Ianoni por seus comentários e sugestões. Luiz Carlos Bresser-Pereira é professor emérito da Fundação Getúlio Vargas. bresserpereira@gmail.com, www.bresserpereira.org.br. 
core thesis of developmental nationalism is that the promotion of economic development and the consolidation of nationality stand as two correlated aspects of a single emancipatory process." Through national-developmentalism - a term that became consolidated as the development strategy's denomination - Brazilian society was successfully overcoming the patrimonial state that characterized Brazilian politics until 1930. Other Latin-American countries, Mexico in particular, and Asian ones, such as South Korea, Taiwan and Singapore, grew by embracing a developmental strategy that was theoretically grounded on a combination of structuralist development theory and Keynesian macroeconomics. These countries combined state intervention with a dynamic private sector, modeling themselves after Japan. In the early 1980s, Chalmers Johnson (1982), in an attempt to understand this country's extraordinary economic development, called the Japanese state a "developmental state". ${ }^{1}$ However, notwithstanding the extraordinary success of these countries and the foreign exchange and fiscal responsibility that usually went hand-inhand with successful experiences, over the 30 Neoliberal Years of Capitalism (1979-2008), developmentalism became a derogatory term synonymous with fiscal irresponsibility or populism. The rhetorical maneuver was part of the new neoliberal and neo-classic hegemony's affirmation, but not entirely devoid of grounds. Indeed, since the late 1970s, faced with the crisis that the second energy shock brought about, several Latin-America countries refused to carry out the required macroeconomic adjustments and embraced populism in the name of Keynesianism. This created room for neoliberal hegemony in the region. In the 2000s, however, as the liberal state and its neoliberal policies and reforms failed to make good on their promises and led to sluggish growth, high financial instability and a marked increase in inequality, developmentalism resurfaced and became the subject of growing attention in developing countries. It reappeared both as an actually existing historic phenomenon, reflected in the poll victories of leftist governments one might identify with social-developmentalism often sliding to left-wing populism, and as a theoretical framework and development strategy. In the latter condition, economists and other social scientists, including the author of this paper, proposed a new approach to the problem: new developmentalism as a replacement for Latin-America's classical developmentalism or structuralism, which had become outdated in various ways, particularly for its lack of an appropriate macroeconomics for middle-income countries. ${ }^{2}$

The new instances of popular administrations took place within the framework of democracy and were attempts at building a developmental and social state. ${ }^{3}$ They tried to combine economic development and reduced inequality, but the experiments ended up more social than developmental; they successfully reduced inequality, but, in most cases, failed to foster economic development and catching up, because they allowed themselves to be lulled by fiscal populism - of whose hazards the political leaders were well aware - and the exchange-rate populism in which popular leaders and orthodox economists usually incur without being aware of it. ${ }^{4}$ New developmentalism, the novel theoretical landmark, is an attempt to refresh economic development theory, and its developmental macroeconomics is based on the tendency toward cyclical and chronic overvaluation of the exchange rate, in the same way that classical developmentalism was based on a tendency toward the deterioration of the terms of trade. New developmentalism's analysis focuses on the necessary balance of the five macroeconomic prices - the profit rate, the interest rate, 
the exchange rate, the wage rate, and the inflation rate - that the market is unable to make right. Right not because determined by the market, as neoclassical economists want, but because they are consistent with financial and price stability, and they allow that the competent business firms are competitive and invest. On the other hand, its political economy is based on a social structure wherein the bourgeoisie and technobureaucrats share power and privilege, on a strategic role for the publicsector technobureaucracy, on the concepts of developmental state and developmental capitalism, on the discussion of economic nationalism, and on class coalitions.

The developmental state is associated with the developmental class coalitions that led the formation of the nation-state and the industrial revolution, that is, the capitalist revolution. In the countries that first industrialized - England, Belgium and France - these were nationalist and developmental political coalitions arising from the political alliance between the absolute monarch and their court - that is, sectors from the former dominant class - and the emerging bourgeoisie. In Germany under Bismarck, the state was able to associate sectors from the landed aristocracy with progressive and bourgeois classes. In Brazil, the coalition of classes that Getúlio Vargas formed included the industrial bourgeoisie, urban workers, the thenemerging modern public bureaucracy, and sectors from the former oligarchy of landowners that supplied the domestic market instead of exporting. In the case of the mercantilist coalition, the two groups were interested in forming a large sovereign politico-territorial society - the monarch was interested in power, the bourgeoisie in the large domestic market that the alliance provided. Shared interests were also present in those early developmental class coalitions. They were authoritarian because the state was absolute; they were nationalist because they turned relatively heterogeneous peoples into sovereign nations; and they were developmental because, in addition to being nationalist, they implied moderate market intervention from the state to foster economic development.

The main outcome of the capitalist revolution - the second-largest change humanity has ever undergone ${ }^{5}$ - was the emergence of the nation on the societal level; the formation of the nation-state on the political level; and the beginning of a new historic process - economic development - on the economic level. Nation, modern state, nation-state and economic development result, therefore, from the capitalist revolution; they are particular political and economic realities of modernity. Nation means a politically organized society that shares a common history and destiny; the state is the legal-constitutional system and the organization that supports it; the nation-state is the sovereign politico-territorial unit formed by a nation, a state and a territory; and economic development is the capital accumulation process with the incorporation of technical progress, which raises the population's living standards in the long run. The modern state is the main institution regulating or coordinating capitalist societies. The form that the state assumes, capitalism also assumes. Thus the modern state and capitalist societies were born developmental, since mercantilism was the first really existing developmentalism and the mercantilist state, the earliest form of the modern state.

Using the early development countries as benchmarks, one may state that they have followed a historic path of economic, political, social and environmental development that may be summarized in a few stylized sentences: in the late Middle-Ages, certain 
absolute monarchies allied with the nascent bourgeoisie overcome feudal lords and for a state that is absolute on the political level, patrimonial on the administrative level, and mercantilist on the economic level. And in this way the territorial unit becomes a nation-state as its elites and its people gradually constitute a nation. The new and large domestic market of the mercantilist state goes on to enable the industrial revolution and the appearance of a national bourgeoisie and a large working class. Notwithstanding the fact that the capitalist revolution was completed within the framework of a developmental state, starting in the 1830s this state begins to be replaced with a liberal state in countries that had already undergone the industrial revolution. The liberal state would last for one hundred years in the United Kingdom and in France. From the Crash of 1929 and the Great Depression, emerges the New Deal, and from the war, the Golden Age of Capitalism, which is the second developmentalism, marked by moderate intervention of the state in the economy, an active macroeconomic policy, high financial stability, fast growth, reduced inequality and a developmental and social class coalition - Fordism. ${ }^{6}$ But this new phase was to last for about 30 years, before once again giving in to economic liberalism, which lasted for a like period and entered a deep crisis with the Global Financial Crisis of 2008. ${ }^{7}$

I will not cover each phase of the long-term process. The purpose of this paper is to understand the logic of the developmental state within the framework of capitalism and the four historical models that it assumed in leading the industrial and capitalist revolution. In it, the two institutions par-excellence for economic and social coordination are the state and the market. While the market is devoid of will (albeit not of the interests of those in it), the state is the law and, therefore, ever political will. It is through the state that collective action takes place; it is through it that nations regulate social life in pursuit of the political objectives that modern societies have set for themselves: security, liberty, well-being, social justice, and protection of the environment. It is through the market that companies compete with each other, that prices are formed, and that the allocation of resources across the various competitive sectors of the economy takes place efficiently. It is through the market that the economy's competitive sectors are coordinated, and it is through the state that the market is regulated, that non-competitive industries are coordinated, and that, through active macroeconomic policy, one may ensure macroeconomic balance and create the conditions needed for businesspersons to invest and innovate, for full employment to be attained, and for economic development to occur in sustained fashion.

Use of the term developmentalism began in Brazil - and perhaps worldwide - in the 1950s to designate, on the one hand, a form of organization of capitalism and, on the other, a theoretical approach. Pedro Cezar Dutra Fonseca (2014: 36), who carried out a comprehensive study on the origins of the term, found them first occurring in the works of Hélio Jaguaribe (1962) and Bresser-Pereira (1963). ${ }^{8}$ Starting in the 1970s, the term "national developmentalism" found widespread use. Internationally, however, the term only gained momentum with Chalmers Johnson's book (1982) on the Japanese Ministry of Economy Trade and Industry (MITI), in which the Japanese state was defined as a "developmental state". 
Over history, the developmental state took on many forms or models, which I will attempt to analyze in this paper. It is divided into four sections. Section one discusses developmental state as a concept and attempts to define its "logic" within the framework of capitalist societies. In section two, I offer that capitalist revolution have always taken place within the framework of a developmental state, but one must distinguish four models of developmental state depending on whether the industrial revolution took place at the center, or periphery of capitalism, and independently, or in national-dependent manner. In section three I point out that, once the capitalist revolution has been completed, the market as an institution becomes increasingly developed and, as a result, state intervention gradually wanes, but the State remains or should remain developmental because it pursues growth with stability, reduced inequality and protection of the environment. In the final section, I briefly discuss the relationship between nationalism and developmentalism.

\section{The developmental state defined}

The presence of the developmental state throughout the history of capitalist development is not the product of chance. The logic of the nation-state is that of economic development and competition. As Ernest Gellner (1993) put it, the nationstate opposes the classical, or pre-industrial, empire. The empire is the politicalterritorial unit that characterizes more developed ancient societies - those that Gellner refers to as "agro-literate societies" - whereas the nation-state is the politicoterritorial society particular to capitalism. ${ }^{9}$ It is no accident that today, within the framework of global capitalism, nation-states cover the entire surface of the Earth. The nation-state is the means to politically organize the nation and its territory that best accomplishes the logic of capitalism: capital accumulation, profit, and economic development. While the classical empire, whose final representatives were the Austro-Hungarian Empire and the Ottoman Empire, did not attempt to integrate colonies into its superior culture, but simply force them to pay tribute, the fundamental logic of nation-states is to socially integrate the peoples that form its territory as a means to enhance competitiveness. For Gellner (1993: 116), this transfer of the superior culture - now an operational culture aimed at increasing productivity - takes place within the framework of the nation-state, and has public education as its main instrument because "work has become semantic and work requires impersonal context-free communication between individuals, members of broad mass. This can only be done if the members of that broad mass share the same rules for formulating and decoding messages".

Capitalist competition does not occur among business firms only, but also among nation-states. For Gellner (1983: 32), industrial society is "ultimately, a society based on economic growth...," a society in which there is "the hope of perpetual increase of satisfactions and whose legitimacy depends on their ability to meet this expectancy." Since the capitalist revolution, the logic of empires - that of permanent war to reduce neighbors to colonies - became outdated. Appropriation of economic surplus no longer depended on wars being waged, but on the realization of market profits. This didn't prevent wars to continue among leading countries for three centuries, from the Peace of Westphalia (1648) until the end of the Second World War. But there was an important difference: the logic behind war was no longer to reduce neighboring 
peoples to colonies as a means to enslave them or force them to pay tribute, but rather to expand the borders of the nation-state, assuring its business firms the biggest and most secure domestic market possible - a condition for their industrialization. Therefore, when the richer nation-states became the destination of a growing number of immigrants from poorer countries, these were required to integrate into the nation-state's culture, so as that they shared the basic culture required by productive work and capitalist competition. At the same time, as the people of each country that realized its capitalist revolution assured civil rights and democracy, the law system made room for multiculturalism, albeit limited.

In sum, the logic of nation-states, or countries, is one of economic growth that the state, as an organization and as laws and policies, must foster. The modern state assumes two basic forms in regulating capitalist economies - developmental and liberal - that are also the two forms of economic and political organization for capitalism, given that the state is the fundamental institution of modern societies. Chalmers Johnson $(1982,1999)$ defined the developmental state as a state that has economic development as a priority objective; one that intervenes in the economy not only by means of regulation, but also "substantively"; one that assumes a small and highly skilled public bureaucracy to which actual powers are assigned, leaving the Legislative and Judiciary powers in the background; one that controls its foreign commercial and financial accounts and, therefore, the exchange rate; one that protects the domestic industry from end-products; one that facilitates machinery imports; one that separates foreign technology, in which it has great interests, from foreign capital, in which it has no interest; the creation of public-sector financial institutions; intensive, but always temporary of credit and fiscal incentives, depending on constant assessments; the adoption of a consolidated publicinvestment budget; strong government support to science and technology; the rejection of detailed laws, making room for the initiative of business firms and discretionary guidance from the public bureaucracy. For Peter Evans (1992), the two characteristics of the 20th century's developmental state were bureaucratic capacity and embeddedness - the public bureaucracy's insertion into society and, in particular, into the business community.

My conception of developmental state is similar, but also includes the states of rich countries that were developmental after World War Two. Besides developmental, or liberal, the modern state may be, following Peter Evans (1992) "predatory", with grey areas present between the three types. The liberal state limits itself to guaranteeing property rights and contracts, controlling the national currency, and to maintaining healthy public finances, leaving all other activities to the market's coordination; the developmental state intervenes moderately in the market, by planning the economy's non-competitive sector and by practicing strategic industrial, embracing, and an active macroeconomic policy; the predatory state, according to Evans (1995: 12) "has no ability to prevent its leaders pursue their own goals; personal relationships are the only source of cohesion, and the maximization of the interests of individuals takes precedence over the common goal." Predatory states exist in pre-industrial countries that have not yet made their industrial and capitalist revolution. Their rulers claim to be developmental or liberal, according to convenience, but this means little or nothing at all. In theory, they may become 
developmental or liberal states, but, should they choose the latter path, their odds of developing and catching up are very poor as we will see in the next section.

The assumption that underlies the forms that the developmental state took on over history is that the market is an excellent institution for coordinating competitive economic activity, but is powerless relative to non-competitive activities, and a poor coordinator of macroeconomic prices - the profit rate, interest rate, foreign exchange rate, wage rate and inflation rate - even when the public budget is balanced. To continue defining the developmental state, it is the state of a "mixed economy" (another name for developmental capitalism); the state in which a developmental coalition of classes formed by businesspersons, workers, public bureaucrats and sectors from the old dominant class holds political power and embraces a national development strategy, thereby standing in opposition against a conservative and liberal coalition made up of sectors from the old dominant class, rentier capitalists and the financiers who manage the former's funds. Chalmers Johnson and Peter Evans credit to the public bureaucracy a strategic role in the developmental state, which is appropriate, but industrial entrepreneurs also have a decisive part to play. In the 20th century, on the periphery of capitalism the developmental state was authoritarian and exclusionary; it faces a bigger challenge in the 21st century, because it now attempts to add together economic development with reduced inequality and protection for the environment, all within the framework of democracy.

One important issue is whether or not agrarian elites take part in developmental class coalitions. As Marcus Ianoni (2014: 99) noted, "in South Korea and in Taiwan, rural society converged with industrial progress, rather than seeking independent political affirmation". The same can be said of the German agrarian elites that Bismarck successfully brought into his political agreement. In Brazil, it is common to argue that the agrarian elites opposed the developmental state, both in the preindustrial period and currently. As concerns agriculture, however, a crucial distinction exists between countries like Brazil, on the one hand, and most European and East Asian ones, on the other. In these, agriculture is essentially domestic-market oriented, while in Brazil coffee and sugar-cane, in the past, and these two plus soybeans and orange juice, in the present day, are meant for export and causes of the Dutch disease - the long-term appreciation of the domestic currency that prevents industrial activity because these commodities can be exported at an exchange rate far more appreciated than the one that makes competent industrial companies competitive. Now, neutralization of the Dutch disease in Brazil's period of rapid development was achieved by means of a tax on exports in disguise that coffee growers called "foreign exchange confiscation" - a tax that led them to oppose industrialization. From the 1930s to the 1950s, however, support from the nonexporting agrarian oligarchy was crucial to the success of Getúlio Vargas's nationaldevelopmental pact.

The definition I propose is not normative, but rather a generalization of the behavior of developmental sates, particularly those in East Asia and Brazil at the time of their industrialization. Assuming that the behavior of developmental states was not too different, let us consider South Korea to summarize its successful catching up: high import tariffs in the 1970 s, in the $30 \%-40 \%$ range, and at $20 \%-30 \%$ in the 1980 s; plenty of non-tariff barriers; large subsidies to exports; small fiscal deficits; low debt- 
to-GDP ratio; a strongly regulated financial market; low, frequently negative, interest rates; strict control over the foreign exchange rate; strict control of capital inflows and outflows; average inflation of $17.4 \%$ in the $1960 \mathrm{~s}$ and $19.8 \%$ in the $1970 \mathrm{~s}^{10}$

\section{Models in the moment of the industrial revolution}

Based on this broad view of the developmental and liberal states on the economic level, I look at the history of capitalist development and spot find a crucial fact: every industrial revolution - the decisive moment in each country's capitalist revolution took place under the lead of a developmental state. To check this statement, it is worth categorizing countries and developmental state models. According to two criteria - the moment when a people gain autonomy, becomes a nation, forms a nation-state, and achieves the industrial revolution, and whether the country in question is at the center or on the periphery of capitalism - one may distinguish four developmental state models in the moment of their industrial revolutions: (1) the original central developmental state model of the countries that industrialized in the 18th and early 19th centuries, such as England and France; (2) the latecomer central developmental state model of countries that were not colonies, but belatedly achieved their industrial revolution, such as Germany and the United States; (3) the independent peripheral developmental state model of countries that were colonies or quasi-colonies of developed countries, but achieved a high level of national autonomy, industrialized, caught up, and became rich, such as Japan, Taiwan and South Korea, or became middle-income countries, like China, India, Malaysia and Thailand; and (4) the national-dependent peripheral developmental state model of countries that did achieve the capitalist revolution, but, after the deep Foreign Debt Crisis of the 1980s, lost some of their national autonomy and started growing at a very slow pace, such as Brazil and Mexico. In addition to these four models of countries where the capitalist revolution has come to pass, there are also preindustrial ones, which are trying to make the revolution right now, and countries that are simply poor; this article is not concerned with either of the latter two.

Under all four developmental-state models, the countries involved achieved a reasonable degree of autonomy and embraced a growth strategy in which the state and the market played important roles. The original central developmental state model has been the subject of study by a large number of scholars, from great economists like Adam Smith and Karl Marx through to historians like Fernand Braudel, Paul Bairoch and David Landes. It unfolded within the framework of a mercantilist developmental state rather than a liberal state. This is why the liberal critique of mercantilism - taken both as a historic phase of capitalism and as economic theory - is misguided. The mercantilist, or absolute, state is that in which the emergence of market economies - the industrial revolution - takes places by intervening in the market to foster national development. It lies seated on a coalition of classes formed by the monarch, his patrimonial nobility (whose revenues come from the state's coffers, instead of land rent), and the large nascent bourgeoisie. Its overarching development strategy is to increase the domestic market by setting the boundaries of as big a nation-state as possible, the means to which include waging war upon war on neighbors to achieve their annexation. And notwithstanding the fact that it is creating a market economy, it does not hesitate to intervene in the 
economy and organize monopolies through which the association between the absolute monarch and the large bourgeoisie, which paid taxes as a means to fund the monarch's wars, increasingly materializes. As for Adam Smith's radical criticism of mercantilist theory, it is quite understandable, not because he was "founding" economic theory (its founders where mercantilist economists), but because he was founding a new school of economics - the Classical School, whose members included brilliant economists like Malthus, Ricardo and Marx. It now is, or should be, common knowledge - at least since Schumpeter's monumental History of Economic Analysis (1954) - that remarkable economists were among the mercantilists.

The latecomer central developmental state model characterized countries such as Germany, Italy, Sweden and the United States. The classic study of this development model comes from Alexander Gerschenkron (1962), who analyzed European countries that developed in the latter half of the 19th century and found in them a larger degree of state intervention. These countries had to face the industrial imperialism of England and France, which, as Friedrich List put it (1846), attempted to "kick the ladder" from under Germany. ${ }^{11}$ In that country, the developmental state was called Bismarckian. The German industrial revolution, led by Otto von Bismarck (1815 -1898), combined state intervention and investment banks, and served as an example for other latecomer central countries. Hélio Jaguaribe, writing about Bismarckian development in 1952, noted that under it the domestic market was reserved for the domestic industry, and that the state played the role of an arbiter between conflicting forces.

In the case of the United States, too, the domestic market was set-aside for domestic manufacturers, but even so the state's decisive role is not as clear because the liberal ideology was so prevalent there that the state's role in the country's industrialization is systematically obscured. Still, its first Secretary of the Treasury, Alexander Hamilton - also one of the three great Federalist philosophers - was a developmental economist. His classic Report on Manufactures (1792), on the need to protect American industry, launched a lasting and consistent policy of industrial promotion that only ended in 1939 - yes, 1939 -, when the United States finally lowered its customs tariffs, which were very high until that point. ${ }^{12}$ According to Paul Bairoch (1993: 40; 51) in the 19th century and until the 1930s, the average import tariff ranged from $35 \%$ to $48 \%$, and was therefore, in the words of this remarkable economic historian "a bastion of protectionism". Ha-Joon Chang provides additional data in the same direction (Chang 2002b: 24-32). My interpretation of such high tariffs as compared to those of the United Kingdom and France, whose tariffs were lowered more than one hundred years prior, is a developmental strategy that neutralized the country's Dutch disease. ${ }^{13}$ The exchange rate in the United States, with its extraordinary natural resources, including oil, was appreciated in the long term because the respective commodities could be profitably exported at a more appreciated exchange rate than that which enabled manufactured goods exports. The tariffs, therefore, were not exactly a "protectionist" system, but rather a means to neutralize the Dutch disease for the purposes of the domestic market.

The third model of developmental state - the peripheral independent model - has Japan for a model. When the Japanese, threatened by Commodore Perry's cannon, were forced to open up to trade with the West, in 1854, they were humiliated. ${ }^{14}$ The 
Meiji restoration of 1868 - the Japanese nationalist revolution that freed the country from the West's tutelage - embraced copying Western technology and institutions as a strategy. Accelerated industrialization occurred in the 40 following years, under the direct command of the Japanese state. This was how they copied the technology. Copying of the institutions came from 1908 to 1910, through the decision to privatize companies in competitive industries. Thus the former Samurai of the Tokugawa period, who took part in the Meiji Restoration as military men, first became a middleclass of bureaucrats and then became businessmen with privatization. Privatization had no ideological meaning: the Japanese simply copied the Western institutional model, which, in the case of competitive companies, assigns the role of economic coordination to the market. Classic works on Japan's latecomer independent development include those by Barbosa Lima Sobrinho (1973) and Chalmers Johnson (1982); by Alice Amsden (1989) on South Korea, and Robert Wade (1990) on Taiwan. Reading these books clearly shows the weight of the state's intervention - or industrial policy - on business firms. What these books lack, except, in part, Robert Wade's, is a more accurate analysis of active macroeconomic policy they embraced. Each of these countries sought, on the one hand, to limit foreign indebtedness and the occupation of the domestic market by multinational companies and, on the other, to keep right the macroeconomic prices - the profit rate, the interest rate, the wage rate, the inflation rate and, above all, the foreign exchange rate. In doing that, the Asian policymakers had a major advantage over the Latin American counterparts: they didn't export commodities, and, so, didn't have to neutralize the Dutch disease. But either ones or the others were not aware of the problem. Corden and Neary (1982) had already published their paper on the Dutch disease, but it appeared as a problem only in the boom times. Only after Bresser-Pereira (2008) paper became clear that the Dutch disease could derive also from a structural variable - Ricardian rents - and that it could be properly neutralized by an export tax on the commodities. ${ }^{15}$

Concerning this third model of industrialization, it is worth mentioning that China, too, confirms the metaphor of flying geese that Kaname Akamatsu (1962) originally proposed. According to the metaphor, Asian countries copied the Japanese model in waves; first came South Korea, Taiwan and Singapore; then came Malaysia and Indonesia; and after these, China and Vietnam. ${ }^{16}$ China, which experienced massive decadence under the West's industrial imperialism since the mid-1800s, made its national and, allegedly, socialist revolution in 1949. The national revolution was completed by the industrial revolution, which was divided into two parts: the former, from 1949 to 1978, under the lead of Mao Zedong (1893-1976), and the latter, from 1989 to 2010, under Deng Xiaoping (1904-1997). Mao thought he was carrying out the first phase in the Chinese socialist revolution, when he was in fact carrying out the first phase of the capitalist revolution: with him at the helm, China stood as an effectively independent nation-state, educated its population and developed infrastructure and basic industry - activities that the state can typically conduct effectively and with reasonable efficiency. The second phase of the industrial revolution involved privatization and production diversification. As it had happened in Japan, the competitive sector of the economy was privatized and left to the care of the market, while the state maintained political control, planned the non-competitive sector and executed active macroeconomic policy to make sure that the five prices, particularly the exchange rate, were correct. In this second phase, in which the 
market takes on a strategic role, China experienced the most extraordinary economic development of all time, superior even to Japan's massive development, achieving an average yearly growth rate of $10 \%$ for 30 years.

The fourth model of developmental state - national-dependent model - was not as successful. Countries in this group were developmental enough to achieve the industrial revolution, but unable to maintain rapid growth rates from 1980 on. In the case of Brazil, its per-capita income, which at grew close to $4 \%$ during the industrial revolution (1930-1980), dropped down to 1.2\% a year from 1981 to 2014). This was also the case of Mexico. While analyzing the two countries' developmentalism in this period Ben Ross Schneider (1999: 278) found in it four basic characteristics: statedependent profits and investment, a developmental discourse in which prevailed the need to industrialize and the role of the state in fostering industrialization, the exclusion of the majority of the population, and a highly institutionalized publicsector bureaucracy. ${ }^{17}$ I would add a fifth characteristic to the foregoing: excessive recourse to foreign indebtedness, which ultimately financed consumption far more than investment, and was the central cause of the crisis and the demise of the developmental state - something that definitely was not present in East Asia's independent peripheral model. This prevented East Asian countries from in the deep financial crisis that was the Foreign Debt Crisis of the 1980s, which interrupted growth Latin American countries, while East Asian countries continued to grow fast.

The main analysts of national-dependent development were Raúl Prebisch, Celso Furtado, Osvaldo Sunkel, Aníbal Pinto, Hélio Jaguaribe and Ignácio Rangel, whose fundamental contributions emerged in the 1950s and '60s. Classic developmentalism argued that, in developing countries, particularly in the early industrialization phase, the market cannot ensure the correct microeconomic prices, and proposed industrial policy. Fifty years later, new developmentalism reserves a secondary but strategic place for industrial policy, and argues that the market is above all incapable of setting the correct macroeconomic prices - principally the rate of profit and the exchange rate - and proposes structural or long-term policies to make the macroeconomic prices right. ${ }^{18}$ Asian technobureaucrats did not have this theoretical framework to rely on, but were impressively able to pragmatically align the correction of microeconomic prices through industrial policy with the maintenance of macroeconomic prices at the correct levels, though active macroeconomic policy.

In the 2000s, the economic development literature formulated the concept of the "middle-income trap" to explain the loss of momentum of the growth of a whole set of countries that it refers to as middle-income, but are on a range of per-capita income that mixes two categories- pre-industrial and middle-income countries, the latter of which are, for me, countries that have already carried out the industrial revolution. ${ }^{19}$ What this literature found was the obvious: countries that grow at high rates (e.g., more than $4 \%$ a year) for a relatively long period of time (e.g., five years), then experience a relatively large drop in growth rates (e.g., under $2.5 \%$ a year). Having identified those periods, which group together radically different types of countries, the literature then attempts to use econometric studies to determine the cause of the deceleration, and finds answers that are simply tautologies like "lack of industrial diversification", or "too high a growth rate", or that are exceedingly generic, such as "insufficient investment in education". 
Indeed, starting in 1980, growth rates plunged for countries with national-dependent developmental states, like Brazil and Mexico. But explaining this radical change requires new historic facts - which the middle-income trap literature does not provide. Nor does Schneider's (1999) explanation, according to which the central difference between Latin American and East Asian countries was the less formal and less powerful bureaucracy of Latin American, which is not a new fact. For sure, a more professional bureaucracy with greater powers in the economic arena would be preferred, but it is worth pointing out that Mexico's and particularly Brazil's and public bureaucracies were strong enough to bring about industrialization before 1980, and no reason exists for them to lose strength thereafter. The two new historic facts that best explain the drop in Brazil's and Mexico's growth rates are the great Foreign Debt Crisis of the 1980s and the West's increased criticism of the developmental state, since the adoption of neoliberalism as an ideology and its practical definition in the shape of the Washington Consensus. These two facts led to the abandonment of the developmental strategy near the end of that decade. The liberal state embraced neoliberal policies, ceased to neutralize the Dutch disease which afflicts the majority of these countries - and began growing slowly except during commodities boom periods, as was the case in the 2000s. Chile has been the exception, but it is worth mentioning that, since the crisis created by the neoliberal experience of 1981-'82, the country changed its economic policy, made it less liberal, and constantly maintained a high tax rate on copper, which has partly neutralized its Dutch disease. ${ }^{20}$

\section{After the industrial revolution}

We therefore have four models of developmental state in the moment that the countries realized their industrial revolution: original central, latecomer central, independent peripheral and national-dependent peripheral. What about after the industrial revolution? Does the developmental state continue to make sense, or should the state then become liberal and let the market play a bigger part? As with have seen, this was in fact the case. In the 30 Golden Years of Capitalism that came after World War Two the state that characterized the period was developmental and social-democratic. It therefore stood as a fifth developmental state model - the Golden Years developmental and social state -, but no longer associated with countries' industrial revolutions. However, an economic crisis in the 1970s made room for a contradictory economic liberalism - neoliberalism -, a conservative ideology based on neoclassical economics and the Austrian theory that endeavored to carry out radical economic reforms that were supported by the conservative, but their radicalness made them incompatible with conservatism. The new state that was borne out of it - the neoliberal state - was a radical attempt to go back to the liberal state of the $19^{\text {th }}$ century. It failed, however. Firstly, because it made no sense to return to an inferior state model; secondly, because capitalism had undergone extraordinary changes, had become much more complex, and required more, and not less, state coordination. Now, after the Global Financial Crisis of 2008 and the collapse of neoliberalism, globalization retrieved and the state resumed a far more relevant role in rich countries, so that their states may remain conservative, but are no longer neoliberal. But nor can one say a return to a developmental and social state similar to the one that was in place after World War Two. These countries are today 
in a transition crisis where the conditions for the strengthening of the social state are not present. One of the causes of the advent of neoliberalism was the competition from developing countries that rich ones started to face as the former began exporting manufactured goods. This began in the 1970s and rose to new levels with the entry of China in the 1990s. Now, together with the problem of migration to rich countries, competition from countries with access to cheap labor has been one of the root causes of the crisis of the social-democracy state, and of the appearance of a nationalist far right in Europe. ${ }^{21}$

The market gains a more relevant coordinating role after a country becomes capitalist, but this is not to say that the state must cease to be developmental. As we have just seen, the Golden Years of Capitalism corresponded to a second developmentalism for the central original countries. Yet, in the developed societies market coordination is more relevant than in developing countries. The political explanation lies in the rentier and financier capitalists definitive preference for economic liberalism, and the growing ideological hegemony of this social class in relation to the productive entrepreneurs. The economic explanation lies in the increased economic diversity arising from economic development. As economic activities become more diversified, compared to the level of diversity existing in the infrastructure and basic industry companies in the non-competitive sector, the market becomes more efficient an institution than the state for the purposes of coordinating the immense and diversified number of business firms that then emerge. While it is relatively easy for the state do plan and coordinate the infrastructure, and the market has no chance of doing it, the market is a more appropriate institution when it comes to coordinating diversified activities involving creativity and innovation. This is why it is predictable, once a country's industrial revolution has been completed, for market-based coordination to gain ground on coordination by the state. But this is not to say that the developmental state disappears, as liberal economists would have it. Instead, the state's economic role changes. Now, in the economic domain, the state is essentially supposed to create the general conditions making the competent business enterprises in the country competitive and ready to invest, what means keeping the five macroeconomic prices (the profit rate, the interest rate, the exchange rate, the wage rate, and the inflation rate) right - something that the market definitely does not achieve to do - and also means planning and partially investing on infrastructure and basic industry, adopting a strategic industrial policy, fostering scientific and technological development, promoting reduction of economic inequality, defending the environment, which is a public patrimony, and, for sure, guaranteeing property rights and contracts. Therefore, once the industrial revolution has been completed, the state gradually retreats fully from competitive industries and partially from the non-competitive ones - what means limiting public investments to around one fifth of total investment -, because the market is better equipped to coordinate the competitive activities, but, if it is a developmental state, it will continue to coordinate the monopolistic sector of the economy and exercise active macroeconomic policy. ${ }^{22}$

The main problem facing developmental and liberal states alike is the political and economic competence of their rulers. Successful developmental states have always relied on republican-minded nationalist politicians and pragmatic economists who knew that their core job was to ensure economic stability and make policies that 
contributed to their country's industrialization or productive sophistication. Such competent politicians and economists are not always to be found. Politicians often give in to the temptation of raising people's incomes without the required increase in production, incurring in economic populism, be it exchange-rate populism, under which the country incurs large current account deficits, be it fiscal populism, when the state incurs large public deficits. In either case, the result is increased consumption and indebtedness - domestic, foreign, or both. One must not, however, imagine that the liberal state avoids these problems. Exchange-rate populism is a more common practice in this model of state than in developmental states. The liberal politicians and economists that govern developing countries believe in the thesis - very dear to rich countries - that current-account deficits are foreign savings, which, added to domestic ones, increase the country's investment rate. They do not know or care that a high rate of substitution of foreign for domestic savings exists in developing countries, where marginal propensity to consume is high. More broadly and against every piece of evidence - they believe that the market correctly sets the foreign exchange rate, so that the government should not intervene in it. In developmental states, on the other hand, even if until recently no theory existed to legitimize foreign exchange policy, pragmatic foreign exchange rate management policies are commonly adopted because developmental economists know that strategies based on industrialization depend on the foreign exchange rate. ${ }^{23}$

\section{Developmentalism and nationalism}

The developmental state is necessarily nationalist because economic nationalism (not, ethnical) is the ideology of the nation-state and developmentalism is the development strategy for the very same nation-state. The two central ideologies of modern societies are nationalism and economic liberalism. These are two capitalist ideologies that serve two central and contradictory needs of the capitalist class: nationalism, which assumes the state's commitment to the interests of the national business enterprises and a basic social solidarity in competing with other countries, while economic liberalism stands for the assurance that each businessman may pursue market profits at the lowest taxation possible and class and individual conflict as long as competition is the overarching rule. Economic liberalism appears to be more influent than nationalism because the ruling classes to not hesitate to declare themselves liberal, while they hardly admit themselves nationalistic. The explanation is simple: first, because nationalism is an exclusivist ideology, as it gathers citizens together around national interests, which are often incompatible with the interests of other countries; second, because nationalism is a dangerous ideology when it has an ethnic content. Economic liberalism, in its turn, is a universal ideology that takes no account of nation-states. One may claim to be liberal and at the same time solidary with the interests of all. In addition, in the case of more powerful countries (both on the global and regional levels), nationalism melds with imperialism - the determination to occupy the domestic markets of weaker countries, so that the former have an interest in hiding or disguising their nationalism, which is strong insofar as their citizens have no doubt that it is their government's duty to protect the interests of their business firms domestically and, above all, abroad. 
On its hand, developmentalism is the ideology and the form of political and economic organization of capitalism where the developmental state adopts economic nationalism and intervenes moderately in the economy to promote economic growth. Thus, we may say that in practical terms developmentalism is economic nationalism; is nationalism freed from any ethnical traits; is the ideology alternative to economic liberalism; is the form of economic and political organization of capitalism between economic liberalism and state, between exclusive economic coordination by the market and exclusive economic coordination by the state.

A nation's autonomy and cohesiveness is the central political condition for development. No historic or empirical case exists of true economic development under colonial circumstances, while terrible experiences exist of the decadence of societies that enjoyed a certain level of prosperity and industrialization, a illustrated by China and India during the 19th century and the first half of the 20th. It was only since their independence, just after World War Two, that these countries began to develop and recover lost ground. Nationalism is a condition for economic development because capitalism is essentially competitive and, contrary to the teachings of neo-classical economics, this competition is not only among business firms, but also among nation-states. The competition is relatively even among central countries; not so when competition takes place between rich and developing ones. In this case, peripheral countries must challenge the domination of the former to achieve their own capitalist revolution. When successful in this endeavor, they become powerful competitors due to their cheap labor and ability to copy more advanced countries' technology. To do so, however, they must have a degree of national autonomy capable of enabling building a nation, setting a national development strategy, and preventing domestic markets from being occupied by multinational companies without true compensation - a level of independence that dynamic East Asian countries in particular proved to have after World War Two. ${ }^{24}$

The capitalist revolution in Latin-American middle-income countries may be considered incomplete. Argentina, Brazil, Mexico, Chile and Uruguay have all accomplished their industrial revolutions, but, given the contradictory, nationaldependent nature of their economic, political and intellectual elites, failed to complete the national revolution, which is an integral part of the capitalist revolution. That is, they did not manage to form a sufficiently independent nationstate to face prescriptions and pressures from rich countries. Party because their elites' European origins induce them to identify with the elites of rich countries, instead of associating with their own people, as befits a nation. Within these elites, the industrial elites are strategic to the formation of a developmental pact, but they remain contradictory or ambiguous; in some cases, when the performance of their firms depends on the domestic market and on a policy that favors industrialization, they identify with their people; in others, particularly when they feel threatened by class struggle, the industrial elites ally themselves with their own country's dependent and liberal elites. As a result, countries of this fourth model of developmental state often lack the autonomy needed to make economic policy comparable to that embraced by the ruling elites of dynamic East Asian countries. I identify these elites as "national-dependent" - an intended oxymoron to indicate the ambiguity intrinsic to Latin-American elites. While countries such as China or South Korea know how to face the problems of development in terms of national interest, 
national-dependent societies are contradictory because they are often subject to the ideological hegemony of rich countries, which are not interested in their development, but rather in the occupation of those domestic markets by their own companies. In other times, national interests - particularly those associated with the domestic market, which is the core asset of every nation-state - do prevail. We therefore find that the local elites, under certain circumstances, do become "national" - that is, capable of formulating national development strategies.

\section{Conclusion}

In conclusion, economic development is a historic process of increasing productivity and wages, arising from the use of increasingly skilled or sophisticated labor in activities of greater value added per-capita. It is the product of a coalition of classes that associates politicians and public bureaucrats with the businessmen responsible for investment and innovation. Within this framework, the developmental state historically has been and must continue to be the central development-oriented institution because it is the state that guarantees and regulates another equally fundamental institution: the market, a merely economic institution. The scope of the state is far greater. It is the par-excellence instrument for the nation to attain the five major political objectives of modern societies: security, liberty, economic well-being, social justice, and protection of the environment - which objectives must constantly submit to compromises or the principle of reasonability in the light of perceived or real short-run conflicts with each other. Economic development is necessarily the outcome of a national development strategy, the result of a strong nation that has showed the ability to build an equally strong or capable developmental state. Nations only form and remain alive and strong when they are the product of a constantly renewed national agreement. If the social contract that binds them together is not sufficiently sound, if the social classes that form it do not maintain basic solidarity bonds when it comes to competing internationally, they will not stand as true nations, the country will be far more vulnerable to hegemonic Western thinking, and the nation will lose strength, as did Latin-American countries after the great crisis of the 1980s.

The developmental state, which lies between the liberal state and statism, is a superior form of capitalist economic and political organization. It is a means to sensibly or pragmatically combine state- and market-coordination in capitalist economies. Throughout history, the developmental state has taken on several models, depending on whether its development was original or latecomer, central or peripheral, first- or second-wave. Every industrial revolution took place within the framework of developmental states, when a group of nationalist politicians successfully forms a nation-state and industrializes. In this phase, the role of the state is always dominant. The state then manages to regulate a broad and comprehensive market, and activities in the competitive sector of the economy - now more diverse and involve more creativity and innovation - may then be advantageously coordinated by this market. But the state must and tends to remain developmental, because it is responsible for coordinating the non-competitive sector of infrastructure and basic industry, implementing active macroeconomic policy, 
including a foreign exchange policy, reducing economic inequality, and protection the environment - a set of activities that the market cannot accomplish.

\section{References}

Akamatsu, Kaname (1962) "A historical pattern of economic growth in developing countries", Journal of Developing Economies 1(1) março: 3-25.

Amsden, Alice H. (1989) Asia's Next Giant. Oxford: Oxford University Press.

Autor, David H., David Dorn and Gordon H. Hanson (2016) "The China Shock: Learning from Labor Market Adjustment to Large Changes in Trade", NBER Working, Paper No. 21906, January 2016.

Bairoch, Paul (1993) Economics \& World History. Chicago: Chicago University Press.

Barbosa Lima Sobrinho, Alexandre (1973) Japão: O Capital se Faz em Casa, Rio de Janeiro: Editora Paz e Terra.

Bresser-Pereira, Luiz Carlos (1963) "O empresário industrial e a Revolução Brasileira" [The industrial entrepreneur and the Brazilian Revolution], Revista de Administração de Empresas 2(8):11-27. English version available in www.bresserpereira.org.br.

Bresser-Pereira, Luiz Carlos (2008) "The Dutch disease and its neutralization: a Ricardian approach" (2008) Brazilian Journal of Political Economy 28 (1): 47-71.

Bresser-Pereira, Luiz Carlos (2016) "Reflecting on new developmentalism and classical developmentalism", Review of Keynesian Economics. Approved to be published.

Bresser-Pereira, Luiz Carlos, José Luis Oreiro and Nelson Marconi (2015) Developmental Macroeconomics. London: Routledge.

Bresser-Pereira, Luiz Carlos and Marcus Ianoni (2015) "Developmental class coalitions: historical experiences and prospects". Texto para Discussão EESP/Fundação Getúlio Vargas n.386, March 2015.

Canitrot, Adolfo (1975) "La experiencia populista de distribución de renda" [The populist experience of income distribution], Desarrollo Económico 15(59): 331-51.

Chang, Ha-Joon (2002a) "The East Asian model of economic policy", in Evelyne Huber, ed. (2002) Models of Capitalism: Lessons for Latin America. Pennsylvania: Penn State University Press: 197-236.

Chang, Ha-Joon (2002b) Kicking Away the Ladder. London: Anthem Press.

Corden, W. M. and J. P. Neary (1982) "Booming sector and de-industrialization in a small open economy", Economic Journal 92 (368): 825-848.

Diaz-Alejandro, Carlos (1981 [1991]) "Planos de estabilização no Cone Sul", in Luiz Carlos Bresser-Pereira, org. (1991) Populismo Econômico. São Paulo: Editora Nobel: 75-106. Publicação original em inglês, 1981.

Eichengreen, Barry, Donghyun Park, Kwanho Shin (2013) "Growth slowdowns redux: new evidence on the middle-income trap", NBER Working Paper 18673, January 2013.

Evans, Peter (1992) "The state as problem and solution: Predation, embedded autonomy, and structural change", in Stephan Haggard \& Robert Kaufman, eds. The Politics of Economic Adjustment, Princeton: Princeton University Press, 1992.

Evans, Peter (1995) Embedded Autonomy, Princeton, NJ: Princeton University Press. 
Fonseca, Pedro Cezar Dutra (2014) "Desenvolvimentismo: a construção do conceito" [Developmentalism: the construction of the concept"], in André Bojikian Calixtre, André Martins Biancarelli and Marcos Antonio Macedo Cintra, eds., Presente e Futuro do Desenvolvimento Brasileiro, Rio de Janeiro: IPEA: 29-78.

Fukuchi, T. e M. Kagami (1990) Perspectives on the Pacific Basin Economy: a Comparison of Asia and Latin America. Tokyo: Institute of Developing Economies.

Gellner, Ernest (1983) Nations and Nationalism. Ithaca: Cornell University Press. Gellner, Ernest (1993 [1996]) "The coming of nationalism and its Interpretation: The myths of nation and class". In Gopal Balakrishnan, ed. (1996) Mapping the Nation. London: Verso: 98-145. Originally published in Storia d'Europa Vol I, Turin: 1993.

Gerschenkron, Alexander (1962) Economic Backwardness in Historical Perspective, Nova York, Praeger.

Hamilton, Alexander (1791 [2001]) Report on Manufactures, report to the United States Congress as Secretary of the Treasury. Scanned January, 2001 from primary sources. http://bit.ly/1FaVTTg

Ianoni, Marcus (2014) "Teoria do Estado desenvolvimentista: uma revisão da literatura", [Theory of the developmental state: a revision of the literature"], Sinais Sociais 24: 81106.

Jaguaribe, Hélio (1962) Desenvolvimento Econômico e Desenvolvimento Político, Rio de Janeiro: Fundo de Cultura.

Jankowska, Anna, Arne J. Nagengast and Richard L. Brickman (2012) "The middle-income trap: comparing Asian and Latin American experiences", OECD Development Centre's Policy Insights 96, May 2012.

Johnson, Chalmers (1982) MITI and the Japanese Miracle, Stanford: Stanford University Press.

Johnson, Chalmers (1999) "The developmental state: odyssey of a concept", in Meredith Woo-Cumings, ed. (1999): 32-60.

Karas, Homi and Harinder Kohli (2011) "What Is the Middle Income Trap, Why do Countries Fall into It, and How Can It Be Avoided?" Global Journal of Emerging Market Economies 3 (3) September: 281-289.

Kohli, Atul (1999) "Where do high-growth political economies come from? "The Japanese lineage of Korea's 'developmental state', in Meredith Woo-Cumings, ed. (1999): 93-136.

Kohli, Atul (2012) "Coping with globalization: Asian versus Latin American strategies of development, 1980-2010”, Brazilian Journal of Political Economy 32 (4): 531-556.

List, Friedrich (1846 [1999]) National System of Political Economy. Roseville. Ca: Dry Bones Press, 1999. Originally published in German, 1846.

Lovett, William A., Alfred E. Eckes, Jr, and Richard L. Brinkman (1999) U.S. Trade Policy: History, Theory, and the WTO. White Plains, N.Y.: M.E. Sharpe.

Schneider, Ben Ross (1991) Bureaucracy and Industrial Policy in Brazil. Pittsburgh: Pittsburgh University Press.

Schneider, Ben Ross (1999) "The desarrollista state in Brazil and México", in Meredith WooCumings, ed. (1999): 276-305.

Schumpeter, Joseph A. (1954) History of Economic Analysis, edited by Elisabeth Boody Schumpeter. London: Allen \& Unwin. Republished by Oxford University Press, 1959.

Wade, Robert (1990) Governing the Market, Princeton: Princeton University Press. 
Woo-Cumings, Meredith, ed. (1999) The Developmental State. Ithaca: Cornell University Press.

${ }^{1}$ The term State is usually written with an upper-case "s" - which appears reasonable as a designation of a society's greatest institution, but when we mention the developmental state or the patrimonialist state, as well as when we speak of nation-state, we mean, in the former case, a political system or form of government and, in the latter, to a form of sovereign politico-territorial society, so that I will use the lower case in such instances.

${ }^{2}$ See Bresser-Pereira (2016).

3 Marcus Ianoni (2014) produced a comprehensive review of the literature on the developmental state. A review of the literature on new developmentalism is yet to be produced.

${ }^{4}$ The concept of exchange-rate populism originates from the works of Adolpho Canitrot (1975) and Carlos Dias Alejandro (1981). The concept is central to new developmentalism, whose macroeconomics focus on the foreign exchange rate and on current-account deficits or surpluses.

${ }^{5}$ The first transformation was the invention of agriculture and the appearance of the firs sedentary societies, around ten thousand years before the Christian era.

6 "Fordism" was the name given by the French Regulaltion School gave to the "mode of regulation" of capitalism led by the United States from the New Deal to the 1970s. It was a developmental class coalition characterized by mass consumption, large monopolist and bureaucratic corporations, and some reduction of inequality, in so far that wages grew with productivity and technical progress was capital-saving.

${ }^{7}$ See Bresser-Pereira and Ianoni (2015) for a comprehensive review of historic forms of developmental class coalitions.

${ }^{8}$ Fonseca (2014: 37) also finds references to the term in Paulo Sá and in Celso Furtado. Concerning the latter, however, Fonseca points out that "the term developmentalism is practically non-existent in his work".

${ }^{9}$ The term "politico-territorial" is mine, not Gellner's. Like most political theorists, he did not clearly distinguish between the State (an institution endowed with sovereignty: the legalconstitutional system and the organization that enforces it) from the nation-state or country (a politico-territorial unit).

10 This summary is based on Ha-Joon Chang (2002a) and on a class at the sixth Latin American Advanced Programme on Rethinking Macro and Development Economics (Laporde), São Paulo, January 11, 2016.

11 The expression "ladder kicking" was originally employed by Friedrich List (1846) to describe the behavior of England, which sought to convince the Germans not to industrialize by using the arguments of classical liberal economics. The argument describes the current behavior of rich countries vis-à-vis developing ones. Ha-Joon Chang (2002b) picked up the expression with great competence and propriety. 
${ }^{12}$ According to William A. Lovett, Alfred E. Eckes Jr, Richard L. Brinkman (1999, e-book) the United States, in a 1938 agreement with the United Kingdom, made 621 concessions that added up to US $\$ 457.8$ million and represented $37 \%$ of the country's durable goods imports.

${ }^{13}$ The correct form of neutralizing the Dutch disease (a long-term overvaluation of the exchange rate caused by commodities that may be exported at an exchange rate substantially more appreciated than the one required by other tradable industry non-commodity) is the imposition of a variable retention on the prices of the commodities that originate it. High import tariffs only neutralize the Dutch disease on the domestic market side - on imports; multiple exchange rate regimes may neutralize it on the import as well as on the export side.

${ }^{14}$ By West we mean the group of rich countries on the North Atlantic, plus Australia, New Zealand, Japan, and the three East-Asian one that caught up in the 20th century: South Korea, Taiwan and Singapore. The West is therefore not a geographic concept. Its members make up the modern empire, under the leadership of the United States. These are countries that have in common high levels of knowledge and high wages that they attempt to protect along with the profits of their business firms. They are militarily organized under NATO and their main economic instruments are the International Monetary Fund and the World Bank.

${ }^{15}$ In 1989, in the Tokyo, in a conference organized by the Institute of Developing Economies comparing the natural resource rich Latin American countries and the East Asian natural resource poor countries, none of the economists used the Dutch disease model to explain why the East Asian countries continue to grow fast, while the Latin American fell behind from 1980. The book on the conference is Fukuchi and Kagami (1990).

${ }^{16}$ In the case of South Korea, the Japanese model was imposed in the more than 30 years of Japanese colonial rule, and maintained after the country's independence. As Atul Kohli (1999: 94) points out, by 1940 Korea was already a country with a "relatively high level of industrialization".

${ }^{17}$ As concerns the public bureaucracy, it is worth pointing out that this view applies to the Mexican more than the Brazilian bureaucracy, about which, in fact, Schneider (1991) wrote a fundamental book in which he shows that the Brazilian public bureaucracy was relatively informal, but very professional.

${ }^{18}$ To neutralize the tendency to the cyclical and chronic (in the long-term) overvaluation of the exchange rate, new developmentalism proposes an export tax to neutralize the Dutch disease and the rejection of three habitual policies: growth cum foreign indebtedness ("savings") policy, exchange rate anchor policy to control inflation, and setting a high level for the real interest rate around with the central bank manages its monetary policy.

19 See, among others, Barry Eichengreen, Donghyun Park, Kwanho Shin (2013), Anna Jankowska, Arne J. Nagengast \& Richard L. Brickman (2012), and Homi Karas \& Harinder Kohli (2011).

${ }^{20}$ The tax on copper exports would fully neutralize Chile's Dutch disease if it its rate varied according to the severity of the disease (that is, exchange-rate overvaluation), which, in its turn, varies according to international commodity prices.

${ }^{21}$ About the costs to the United States in its trade with China, Autor, Dorn \& Hanson (2016: 1) concluded that, in addition to high regional costs - from firms that shut down - "At the national level, employment has fallen in U.S. industries more exposed to import competition, as expected, but offsetting employment gains in other industries have yet to materialize". 
${ }^{22}$ Japan's industrialization in the late 19th century was almost entirely carried out by the State; around 1910, however, a rapid and radical privatization process took place. In the case of Russia and China, the revolutions that professed themselves as socialist were in fact national and industrial; paradoxically, they were part of the Capitalist Revolution.

${ }^{23}$ This theory is the new developmentalism and its developmental macroeconomics. See Bresser-Pereira, Marconi and Oreiro (2015).

${ }^{24}$ For a comparison of development in Latin America and Asia, see Kholi (2012) in particular. 